\title{
Hydrogeochemical characteristics and evaluation of groundwater quality for domestic and irrigation purposes: a case study of the Heuningnes Catchment, Western Cape Province, South Africa
}

\author{
Portia Mokoena $^{1}$ (D) $\cdot$ Thokozani Kanyerere $^{1}$ (I) $\cdot$ Jan van Bever Donker ${ }^{1}$ (I)
}

Received: 22 April 2020 / Accepted: 13 August 2020 / Published online: 25 August 2020

(c) Springer Nature Switzerland AG 2020

\begin{abstract}
Knowing the quality of water is imperative if the water is meant for drinking or agricultural purposes. The spatial and temporal groundwater quality in the Heuningnes Catchment was investigated, and its appropriateness for irrigation and drinking purposes was considered. Thirty-one samples were collected and analysed for physical (pH, EC, TDS) and chemical $\left(\mathrm{Na}^{+}, \mathrm{K}^{+}, \mathrm{Ca}^{2+}, \mathrm{Mg}^{2+}, \mathrm{HCO}_{3}{ }^{-}, \mathrm{Cl}^{-}, \mathrm{SO}_{4}{ }^{2-}\right)$ parameters. Maps demonstrating the spatial and temporal distribution of groundwater quality were constructed using Geographical Information System software. These maps indicate variations in the concentration of various water quality parameters in the region. Groundwater in the region is mostly alkaline and is categorised as either fresh, brackish or saline based on TDS classification. Using Piper diagrams, it is shown that $\mathrm{Na}^{+}-\mathrm{Cl}^{-}$water type is the main water type in the area. The quality is mostly influenced by chemical weathering of rockforming minerals. Over $50 \%$ of groundwater in the region is not fit for drinking purposes as established from WHO (2011) and SANS241 criteria. Following SAR criteria, looking at Na\%, PI, MH, KR and salinity hazard for irrigation assessment, it was discovered that shallow groundwater in the region was not fit for irrigation purposes. However, groundwater from deeper boreholes proved otherwise. The study has shown that not all-available groundwater is suitable for either drinking or irrigation. Therefore, it recommends to plant crop varieties that are highly salinity tolerant, as treating the water prior to irrigation would not be economically viable, and it also recommends further exploration to make the available $50 \%$ of groundwater drinkable and to make the shallow groundwater fit for irrigation.
\end{abstract}

Keywords Groundwater quality · Irrigation · SAR · Salinity · Coastal aquifer

\section{Introduction}

Groundwater has become the major source of freshwater supply for many uses such as domestic, irrigation, industrial and ecosystem support across the world $[12,22,33$, $41]$, and this is especially true in coastal areas where the water demand is high because of the increasing population and agricultural activities. Groundwater is important for the Heuningnes community who requires it for domestic usage and irrigation purposes. Therefore, groundwater quality is as essential as its quantity especially because the water quality informs the aptness of groundwater for various uses. The type and concentration of dissolved minerals determine the aptness of water for different uses. A number of factors are considered to have an effect on the chemistry of groundwater thus influencing its quality.

Electronic supplementary material The online version of this article (https://doi.org/10.1007/s42452-020-03339-0) contains supplementary material, which is available to authorized users.

Portia Mokoena, mokoena53@gmail.com | 'Department of Earth Sciences, University of the Western Cape, Private Bag X17, Bellville 7535, South Africa. 
These factors include climatic conditions, rain and surficial water percolation, recharge water quality, regional geology, sub-surficial geochemical processes, as well as discharges, leaching and organic matter addition from anthropogenic activities carried out over the aquifer, extraction and irrigation practices $[11,16,23-25,40]$.

Coastal areas including where this investigation was carried out are inclined to high groundwater demands because of an increasing population size, caused by the influx of people in search for better socio-economic developments, as well as agricultural and tourism opportunities. Kokkat et al. [20] indicate that the proximity of coastal aquifers to the sea, the presence of saline soil and brine, agricultural activities as well as geological, geomorphological and hydrological factors encourage salinity intrusion into aquifers. The geological setting and anthropogenic activities of an area play a role in the prevailing groundwater quality in terms of physical and chemical variations [20]. Globally, irrigated agriculture makes an indispensable contribution to guarantee food security around the world. While only $15 \%$ of the world's farmland is irrigated, approximately $35-40 \%$ of the total supply of food and fibre arises from irrigated agriculture as stated by [7]. However, most areas of irrigated land across the globe are under threat by salinisation and the Heuningnes Catchment is no exception to this. It is therefore vital to have knowledge of the groundwater quality of the area so that proper utilisation and management practices of the resource are implemented and monitored to ensure sustainable availability of such waters in a quality that is fit for use.

Furthermore, understanding the quality of water is important for the region to ensure that people consume water that is of good quality [31]. Also for irrigation water, good quality is required because water that is not fit for irrigation may harm soil structure, affect permeability, plant growth and reduce crop yield [2]. Various researchers $[4,34]$ studied and assessed aptness of groundwater for irrigation using SAR, salinity hazard, $\mathrm{PI}, \mathrm{KR}$ and $\mathrm{MH}$. They assessed suitability of drinking water by analysing major cations $\left(\mathrm{Na}^{+}, \mathrm{K}^{+}, \mathrm{Ca}^{2+}, \mathrm{Mg}^{2+}\right)$ and anions $\left(\mathrm{HCO}_{3}{ }^{-}, \mathrm{Cl}^{-}\right.$, and $\mathrm{SO}_{4}{ }^{2-}$ ). A similar approach as described in these previous studies was adopted in this current study. The lack of information and knowledge regarding the type, origin and quality of groundwater in the area is what motivated this study. The purpose of this study is to provide hydrochemical characteristics of groundwater in the area and evaluate its suitability for irrigation purpose through a multi-methods approach. This study provides baseline information on chemical characteristics of the groundwater in the area that can be used for future developments of groundwater resources and irrigation and to support sustainable management. As it stands, arid and semi-arid regions like the current study require comprehensive knowledge of the geochemical evolution of groundwater for better understanding of hydrochemical systems of such areas.

\section{Description of study location}

The Heuningnes Catchment is located on the southernmost part of South Africa and falls within the Eastern Overberg region in the Western Cape Province (Fig. 1). The catchment occupies a total area of $1400 \mathrm{~km}^{2}$ and is part of the third-order catchments of South Africa [19]. It comprises of a number of surface water bodies which include rivers and wetlands, riparian and non-riparian floodplains, pans and freshwater springs. The main rivers feeding the catchment include Nuwejaar, Kars and Heuningnes rivers (Fig. 1). The main water bodies include Soetendalsvlei which is about $8 \mathrm{~km}$ long and $3 \mathrm{~km}$ wide followed by the Voëlvlei ( $4 \mathrm{~km}$ long and $1.7 \mathrm{~km}$ wide) and some small pans (Soutpan, Longpan and Rondepan).

Bredasdorp, Elim and Napier are the major towns in the Heuningnes Catchment. About $56 \%$ of land coverage is natural vegetation consisting mainly of shrubland fynbos (limestone and sandplain), grassland, bushland, wetlands and water bodies [13]. The main agricultural activities in the area include wheat, vines, orchards and livestock farming [35]. About $41 \%$ of the catchment is agricultural land primarily used for provisional drying agriculture and improved grassland [13]. Field observations reveal that calcareous sands, coarse sands, alluvial topsoils and clays, acidic and highly leached soils dominate the study site. Peat layers are also visible in some areas and often occur between the top sandy layer and clay layer [35].

The average winter temperature ranges from 8 to $18{ }^{\circ} \mathrm{C}$ and average summer temperature from 18 to $25^{\circ} \mathrm{C}$. Expected winds are mostly from the southeast and southwest in summer and westerly in winter. Generally, about $65-75 \%$ of the rainfall occurs in the winter months (May-October) and the mean annual precipitation (MAP) is about $450 \mathrm{~mm}$ (in the east), $540 \mathrm{~mm}$ (in the west) to $650 \mathrm{~mm}$ along the coast [30] and serves as a major source of groundwater recharge.

\section{Geology and hydrogeology}

The basement geology of the area is made up of the metasediments of the Malmesbury Group and the Cape Granite Suite. During the late Precambrian period, the rocks of the Malmesbury Group were deposited and are characterised by alternating layers of greywacke shale and muddy sands [19] which are intruded by the igneous rock of the Cape Granite Suite. Both Malmesbury and the Cape Granite Suite are overlain by the Table Mountain Group (TMG), 


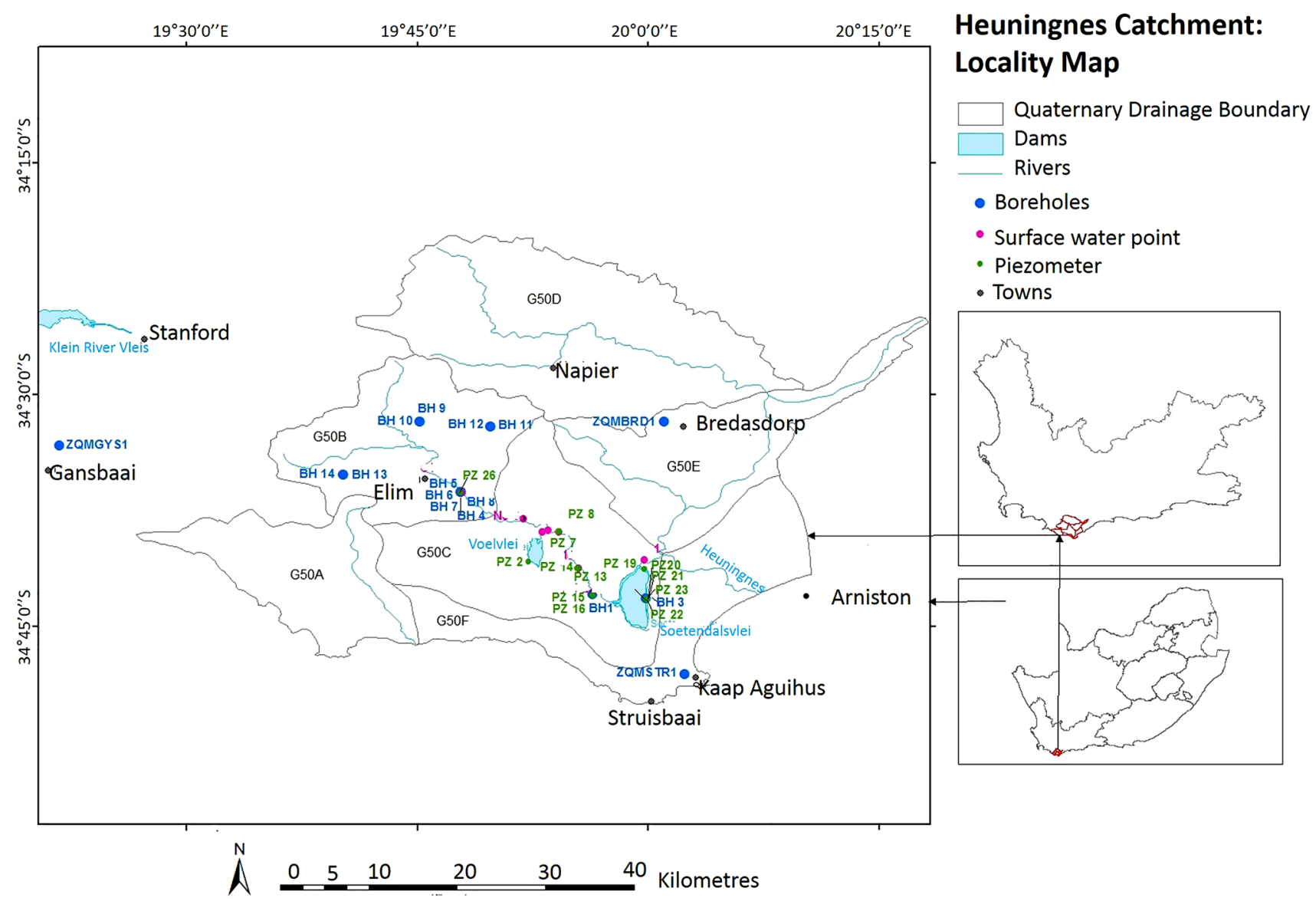

Fig. 1 Study location map of the study area, with sampling points (BH-blue, piezometer-green colour)

which according to [28] underlies the Bokkeveld Group and the Enon Group (Fig. 2).

The study area is locally confined within the TMG and the Bokkeveld Group of the Cape Supergroup. The upper catchment is mainly dominated by the quartzitic sandstones of the TMG which were deposited during the Ordovician, Silurian and earliest Devonian periods [19], whereas the Bokkeveld Group concentrated in the middle section of the catchment is made up of a succession of siltstones, mudstones and fine-grained sandstones deposited in the early to mid-Devonian period. In the Heuningnes Catchment, the Bokkeveld formation is overlain by the Bredasdorp Group found around Soetendalsvlei. The Bredasdorp beds are made up of tertiary and Quaternary deposits of unconsolidated to semi-consolidated shelly sands, basal conglomerate and calcareous sands [28].

In the study area, fractured rock aquifers and alluvial aquifers are the dominant aquifer types and both primary and secondary aquifers are present. The unconsolidated sediments deposited as alluvium in floodplains of the main river systems form the primary aquifers [27]. The secondary aquifers are the TMG and the Bokkeveld Shales. The high fracturing and faulting nature of the TMG aquifer provides high yield attributes for the aquifer as compared to the Bokkeveld aquifers which have a lesser degree of faulting and are generally low yielding aquifers. In terms of water quality, fresh water is often associated with the fractured aquifers of the TMG, whereas the Bokkeveld aquifers yield bad water quality with high concentrations of TDS. Groundwater movement in the area is chiefly associated with secondary structures such as joints, fractures and faults.

\section{Materials and methods}

\subsection{Sampling}

This study took place in an area that did not have a monitoring system; therefore, a new monitoring program had to be developed and that involved drilling of new boreholes and installation of several piezometers. The monitoring system was developed for various objectives, such as groundwater and surface water interaction, 
Fig. 2 Map showing geology of the study area

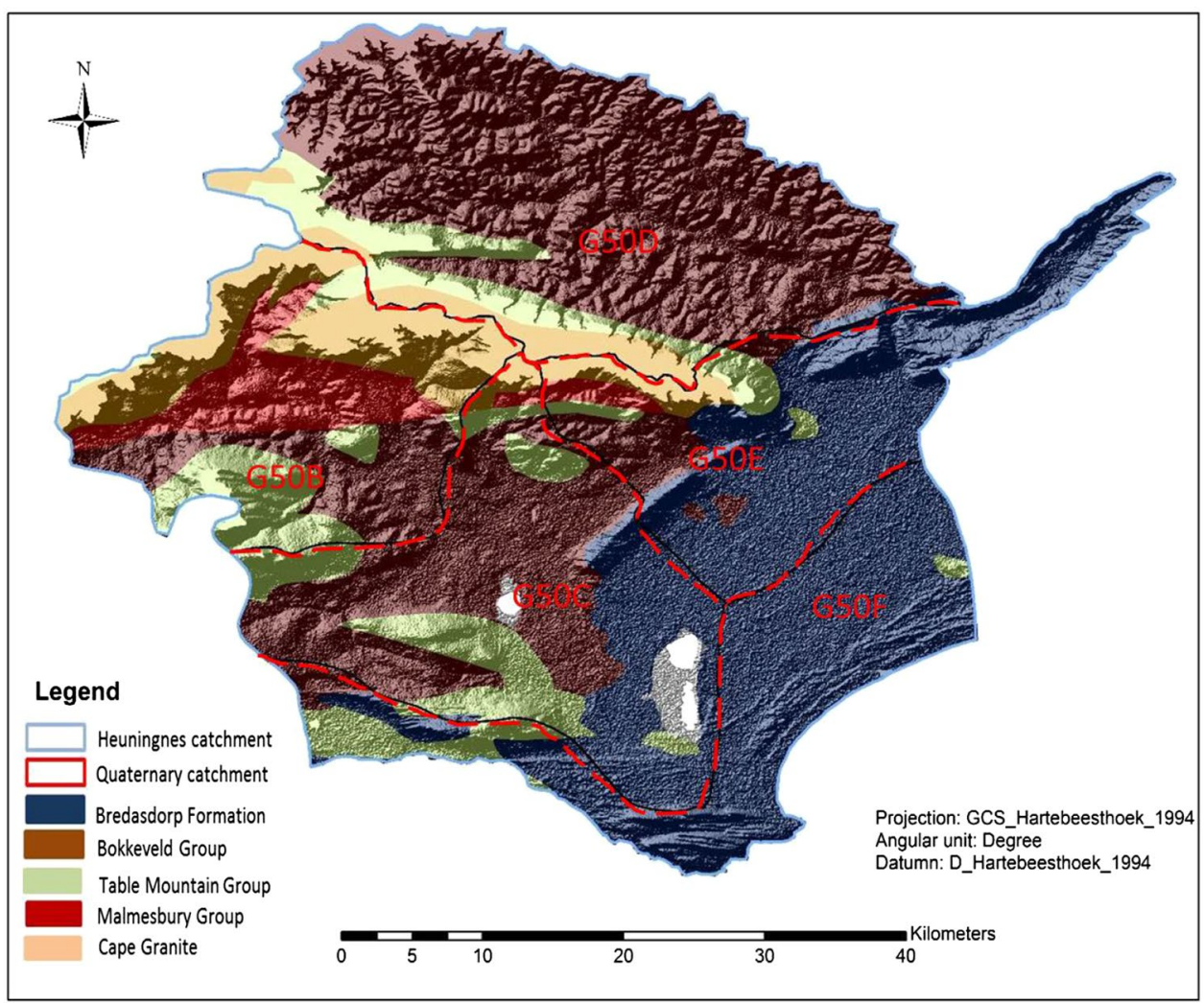

occurrence of groundwater in the area, influence of major faults on groundwater occurrence and to understand groundwater quality and its suitability for various uses which is the focus of this current study. To evaluate the water quality of the Heuningnes Catchment, a total of 31 groundwater samples were collected in July 2017, after the drilling of new boreholes was completed. This includes 22 borehole samples from the deep aquifer (>10 $\mathrm{m}$ depth) and 9 piezometer samples from the shallow aquifer ( $<10 \mathrm{~m}$ depth). The sampling locations were chosen in a way that both upper and lower catchment areas are represented, and catchment groundwater condition is fairly covered. Field measurements of electrical conductivity (EC), temperature and $\mathrm{pH}$ of groundwater were performed onsite with a multi-parameter probe. Total dissolved solids (TDSs) were determined from the EC using the relationship: TDS $(\mathrm{mg} / \mathrm{l})=\mathrm{EC}(\mu \mathrm{S} /$ $\mathrm{cm}) \times 0.64$. Thereafter, groundwater samples were collected for hydrogeochemical parameters, major cations (sodium $\left(\mathrm{Na}^{+}\right)$, calcium $\left(\mathrm{Ca}^{2+}\right)$, magnesium $\left(\mathrm{Mg}^{2+}\right)$ and potassium $\left(\mathrm{K}^{+}\right)$) and major anions (chloride $\left(\mathrm{Cl}^{-}\right)$, bicarbonate $\left(\mathrm{HCO}_{3}{ }^{-}\right)$and sulphur dioxide $\left(\mathrm{SO}_{4}{ }^{2-}\right)$ ) for laboratory analysis. Prior to sample collection, field variables would first be monitored until they stabilized, indicating equilibrium in the instrument's measurements. When these parameters had stabilized, a sample was collected and stored in polyethylene bottles $(250 \mathrm{ml})$ that had been pre-rinsed with diluted sulphuric acid (to $\mathrm{pH} 2.0$ ), for chemical analysis. Samples were kept on ice during transport to the laboratory. Prompt transport of the sample to the laboratories was arranged to prevent degradation of water samples prior to analysis.

The collection of groundwater samples for chemical analysis as well as the measurement of field parameters for water quality was done in accordance with standard sampling procedure [38]. Before collecting water samples from groundwater, physical water quality parameters were measured onsite using an YSI Professional Plus $20^{\mathrm{TM}}$ Multi-parameter sonde. The collected samples were then sent to Bemlabs in Strand, Western Cape, for chemical analysis. All analyses were done according to ISO/IEC 17025 standards using SANS accredited methodology (SANS 11885:2008). The testing laboratories are South African National Accreditation System (SANAS) accredited. Cation analysis was done with inductively coupled plasma optic emission spectroscopy, while anions were analysed using ion chromatography. As indicated in the Bemlabs Methods description document, the uncertainty of measurement among all elements analysed ranged between 0.000 and $8.55 \%$, which is lower than the recommended limit of $10 \%$ for uncertainty [38]. 


\subsection{Evaluation of groundwater quality for irrigation purposes}

The equations listed below were used to evaluate the suitability of groundwater for irrigation purposes. The sodium percentage (Na\%), sodium adsorption ratio (SAR), Kelly's ratio (KR), magnesium hazard $(\mathrm{MH})$ and permeability index (PI) were also calculated by using the standard formulas (Eqs. 1-5). All concentrations were expressed in meq/L.

$$
\begin{aligned}
& \mathrm{SAR}=\left(\mathrm{Na}^{+}\right) /\left[\sqrt{ }\left(\mathrm{Ca}^{2+}+\mathrm{Mg}^{2+}\right) / 2\right] \\
& \% \mathrm{Na}=\left[\left(\mathrm{Na}^{+}+\mathrm{K}^{+}\right) /\left(\mathrm{Ca}^{2+}+\mathrm{Mg}^{2+}+\mathrm{Na}^{+}+\mathrm{K}^{+}\right)\right] * 100 \\
& \mathrm{KR}=\left(\mathrm{Na}^{+}\right) /\left(\mathrm{Ca}^{2+}+\mathrm{Mg}^{2+}\right) \\
& \mathrm{MH}=\left(\mathrm{Mg}^{2+} \times 100\right) /\left(\mathrm{Ca}^{2+}+\mathrm{Mg}^{2+}\right) \\
& \mathrm{PI}=\left[\left(\mathrm{Na}^{+}+\mathrm{HCO}_{3}^{-}\right) /\left(\mathrm{Ca}^{2+}+\mathrm{Mg}^{2+}+\mathrm{Na}^{+}\right)\right] * 100
\end{aligned}
$$

\section{Results and discussion}

\subsection{Chemical composition of groundwater}

Table 1 presents descriptive statistics of chemical constituents of both shallow and deep groundwater samples collected in Heuningnes Catchment. These were compared with World Health Organization standards (WHO, 2011) and the South African National Standards (SANS 241, 2011). Most of the water wells investigated in the area are tapping from both the shallow aquifer $(<10 \mathrm{~m}$ and represented by the piezometers PZ1-PZ13) and the deep aquifer ( $>10 \mathrm{~m}$ and represented by boreholes F1-BH13).

In general, $\mathrm{pH}$ is considered as the primary parameter to measure the quality of water whether it is alkaline or acidic in nature [20]. The $\mathrm{pH}$ scale ranges from 0 to 14 , where $\mathrm{pH}$ below 7 reflects acidic in nature, over 7 is alkaline, and a $\mathrm{pH}$ of 7 is considered neutral [4]. As for drinking water, a $\mathrm{pH}$ value in the range of $6.5-8.5$ is considered as desirable, as by [39] standards.

Groundwater in the area is acidic to alkaline in nature, the $\mathrm{pH}$ ranged from 4.9 to 8.5 with a mean of 6.5 for deep groundwater samples and 6.6-7.5 with a mean of 7.1 for the shallow groundwater samples (Table 1). In terms of suitability for drinking water, $\mathrm{pH}$ in the area is within the recommended limits as stipulated by $[36,39]$. High alkalinity in the area is associated with considerable amounts of calcium, sodium, magnesium and bicarbonate ions, which are known to progressively increase the $\mathrm{pH}$ [5].

A general trend of the anions and cations present in groundwater can be deduced from spatial distribution of EC [31]. The EC ranged from 1354 to $73100 \mu \mathrm{S} / \mathrm{cm}$, and the average is $41,490 \mu \mathrm{S} / \mathrm{cm}$ for shallow groundwater (Table 1), whereas deep aquifer groundwater has a range of $320-13,980 \mu \mathrm{S} / \mathrm{cm}$ with an average of $3018 \mu \mathrm{S} / \mathrm{cm}$ (Table 1). In the study region, high levels of EC are evident from the middle of the catchment increasing towards the sea (Fig. 3). Noting that the acceptable limits for EC in drinking water should be $<1500 \mu \mathrm{S} / \mathrm{cm}, 89 \%$ of shallow ground water and $36 \%$ of deep aquifer samples fall outside this limit and are therefore not fit for drinking purposes.

The range of TDS concentration in shallow groundwater is $907-48,977 \mathrm{mg} / \mathrm{L}$ with an average of $27,799 \mathrm{mg} / \mathrm{L}$, whereas samples from the deep aquifer had a TDS range from 112 to $9367 \mathrm{mg} / \mathrm{L}$ with an average of $1990 \mathrm{mg} / \mathrm{L}$. Following TDS classification as proposed by [8], shallow
Table 1 A summary of the physiochemical analysis of the groundwater samples

\begin{tabular}{lllllllllll}
\hline Parameter & $\mathrm{pH}$ & $\mathrm{EC}$ & $\mathrm{TDS}$ & $\mathrm{Na}^{+}$ & $\mathrm{K}^{+}$ & $\mathrm{Ca}^{2+}$ & $\mathrm{Mg}^{2+}$ & $\mathrm{SO}_{4}{ }^{2-}$ & $\mathrm{Cl}^{-}$ & $\mathrm{HCO}_{3}{ }^{2-}$ \\
\hline \multicolumn{2}{l}{ Shallow groundwater $\mathrm{N}=9$} & & & & & & & & & \\
$\mathrm{SD}$ & 0.3 & $24,555.3$ & $16,452.1$ & 3702.0 & 20.7 & 103.5 & 219.0 & 535.5 & $13,683.2$ & 48.8 \\
Min & 6.6 & 1354.0 & 907.0 & 118.0 & 26.0 & 66.0 & 29.0 & 26.0 & 193.0 & 98.0 \\
Max & 7.5 & $73,100.0$ & $48,977.0$ & $11,383.0$ & 88.0 & 381.0 & 707.0 & 1609.0 & $40,988.0$ & 254.0 \\
Mean & 7.1 & $41,490.4$ & $27,798.6$ & 4771.6 & 61.8 & 225.2 & 355.4 & 399.2 & 9579.6 & 188.7 \\
Deep groundwater & $N=22$ & & & & & & & & \\
SD & 1.1 & 4443.3 & 2989.0 & 1603.3 & 27.6 & 64.6 & 79.4 & 178.0 & 2733.5 & 93.8 \\
Min & 4.9 & 230.0 & 112.0 & 34.0 & 1.0 & 2.0 & 3.0 & 1.0 & 56.0 & 5.0 \\
Max & 8.5 & $13,980.0$ & 9367.0 & 6450.0 & 86.0 & 211.0 & 260.0 & 645.0 & $11,290.0$ & 268.0 \\
Mean & 6.7 & 3018.1 & 1990.8 & 972.6 & 15.3 & 49.1 & 58.8 & 112.2 & 1546.2 & 97.9 \\
WHO & $6.5-8.5$ & 1500 & 1500 & 200 & 12 & 200 & 100 & 250 & 250 & 500 \\
SANS & $5.5-8.5$ & 1700 & 1200 & 200 & 50 & 150 & 70 & 250 & 300 & - \\
\hline
\end{tabular}

All units are expressed in $\mathrm{mg} / \mathrm{L}$ except $\mathrm{pH}, \mathrm{EC}(\mu \mathrm{S} / \mathrm{cm})$

$S D$ standard deviation, TDS total dissolved solids 


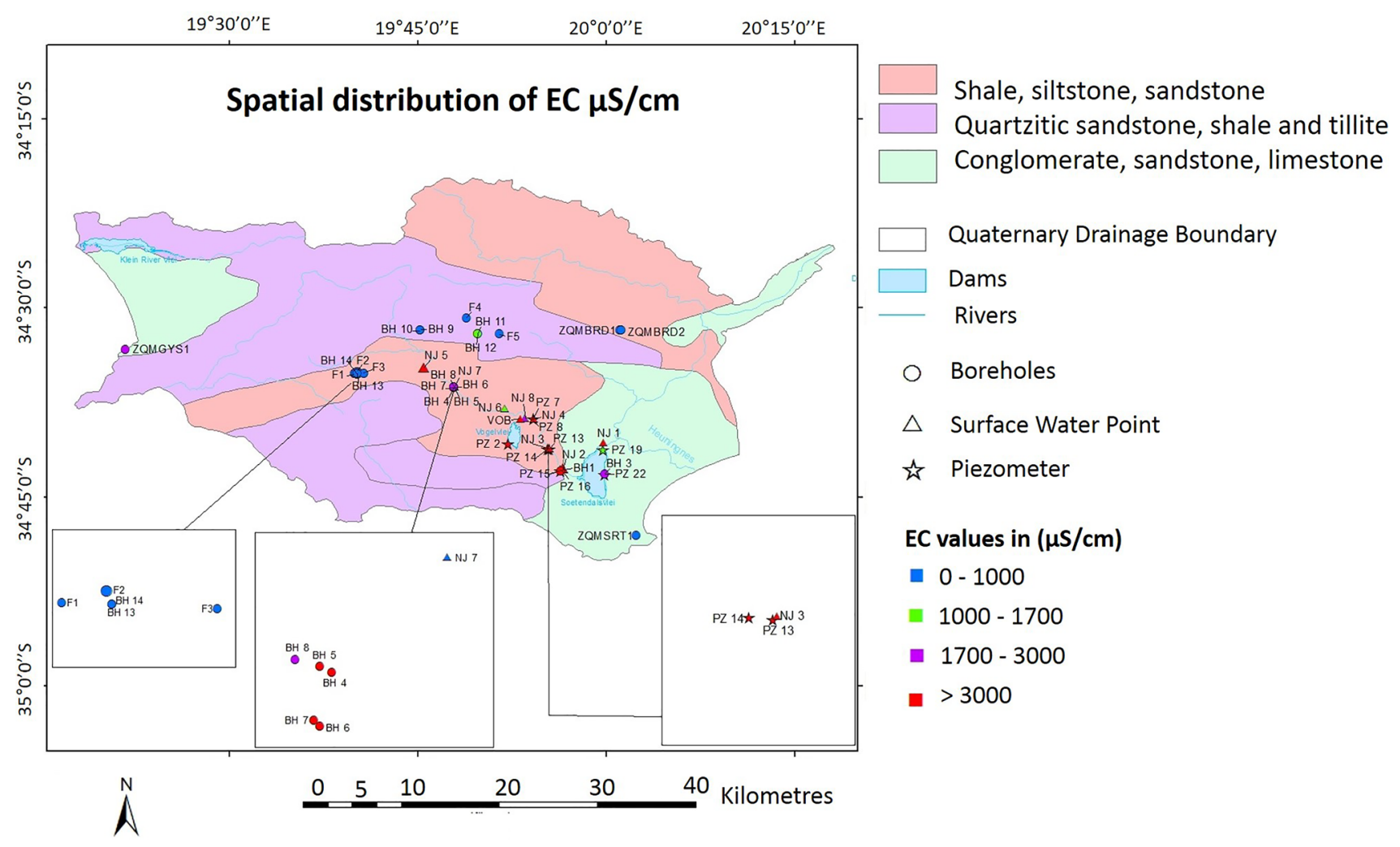

Fig. 3 Map showing spatial distribution of EC $(\mu \mathrm{S} / \mathrm{cm})$

Table 2 Groundwater classification based on TDS after Freeze and Cherry [8]

\begin{tabular}{llc}
\hline Classification & TDS $(\mathrm{mg} / \mathrm{L})$ range & No. of samples $(\%)$ \\
\hline Fresh & $<1000$ & $16(51.6) 15$ from deep aquifer \\
Brackish & $1000-10,000$ & $7(22.6)$ all from deep aquifer \\
Saline & $10,000-100,000$ & $8(25.8)$ shallow aquifer \\
Brine & $>100,000$ & 0 \\
\hline
\end{tabular}

groundwater in the area is saline (Table 2), whereas deep groundwater is classified as fresh (TDS $<1000 \mathrm{mg} / \mathrm{L}$ in 15 samples) to brackish (TDS $>1000 \mathrm{mg} / \mathrm{L}$ in 7 samples). In coastal aquifers, TDS levels in groundwater are raised by higher concentrations of $\mathrm{Cl}^{-}, \mathrm{Na}^{+}$, and $\mathrm{Ca}^{2+}$ when saltwater intrudes and mixes with groundwater [32]. This is true for the shallow groundwater of the study and few samples from the deep aquifer especially those near the ocean. In terms of drinking water standards, $32 \%$ of deep groundwater samples and $89 \%$ of shallow groundwater exceed the highest permissible limits of 1500 and $1200 \mathrm{mg} / \mathrm{L}$ as prescribed by both $[36,39]$, respectively, and are thus not acceptable for drinking. Based on FAO guidelines for irrigation use, only $35.5 \%$ (11) of the samples are permissible for irrigation, whereas $22.5 \%$ (7) are borderline and the remaining $42 \%$ (13) are not to be used for irrigation.
Using water with high TDS for irrigation may cause moisture stress as the water evaporates, and salts accumulates at the roots of the plant causing a blockage, so that the plants are unable to suck water from soil.

The abundance of total cations decreases in the manner of $\mathrm{Na}^{+}>\mathrm{Mg}^{2+}>\mathrm{Ca}^{2+}>\mathrm{K}^{+}$and of anions in the order $\mathrm{Cl}^{-}>\mathrm{HCO}_{3}^{-}>\mathrm{SO}_{4}{ }^{2+}$; however, the sequence changes for the major anions in the shallow groundwater as $\mathrm{SO}_{4}{ }^{2+}$ dominates over $\mathrm{HCO}_{3}{ }^{-}$, and also, the sequence of the major cations changed in a few of the deep groundwater samples (6) where $\mathrm{Ca}^{2+}$ was observed to dominate over $\mathrm{Mg}^{2+}$. The concentrations of chloride for deep groundwater range from 56 to $11,290 \mathrm{mg} / \mathrm{L}$ with a mean of $1546.2 \mathrm{mg} / \mathrm{L}$; for shallow groundwater, the range is from 193 to $40,988 \mathrm{mg} / \mathrm{L}$ with a mean of $9579.6 \mathrm{mg} / \mathrm{L}$ (Table 1). These high $\mathrm{Cl}^{-}$amounts recorded here suggest salty groundwater in the area, and the highest levels recorded in the piezometers and boreholes were at close proximity to the coast. Almost all shallow groundwater samples and few deep groundwater samples exceeded the permissible limits of 250 and $300 \mathrm{mg} / \mathrm{L}$ as stipulated by both $[36,39]$ for drinking water purposes. Application of irrigation water with high $\mathrm{Cl}^{-}$ion concentration of $>350 \mathrm{mg} / \mathrm{L}$ introduces severe problems to the crops such as leaf burn and leaf necrosis [14]. Assessing the specific ion toxicity problem in the area following FAO guidelines indicates that the $\mathrm{Na}^{+}$ 
and $\mathrm{Cl}^{-}$in all shallow groundwater and few deep groundwater samples have been found to be high enough to present toxicity problems (Table 1 ) and are thus not suitable for irrigation purposes.

Bicarbonate, in shallow groundwater, varies from 98 to $254 \mathrm{mg} / \mathrm{L}$, and for deeper groundwater, the range is from 5 to $268 \mathrm{mg} / \mathrm{L}$. In both shallow and deep groundwater samples, the bicarbonate was found to be within the prescribed limit of $500 \mathrm{mg} / \mathrm{L}$ for drinking water according to [39] standards. The concentration of $\mathrm{SO}_{4}{ }^{2-}$ in shallow groundwater ranges from 26 to $1609 \mathrm{mg} / \mathrm{L}$, and for deep groundwater, the range is from 1 to $645 \mathrm{mg} / \mathrm{L}$. Only $44 \%$ of shallow groundwater and $22 \%$ of deep groundwater samples exceeded the allowable limit for drinking standards based on [39].

Freshwater is characterised by lower $\mathrm{Na}^{+}$content than $\mathrm{Ca}^{2+}$ and $\mathrm{Mg}^{2+}$, and excess of $\mathrm{Na}^{+}$in groundwater especially when used for drinking purposes poses a danger to human health in that it can cause hypertension and may aggravate congenital illnesses, kidney disorders and nervous disorders in the human body [2]. It may also have a laxative effect because of the salt content. The $\mathrm{Na}^{2+}$ concentration in the area ranges from 118 to $11,383 \mathrm{mg} / \mathrm{L}$ with an average of $4771 \mathrm{mg} / \mathrm{L}$ for shallow groundwater (Table 1), and for deep groundwater samples, the range is from 34 to $6950 \mathrm{mg} / \mathrm{L}$ with an average of $973 \mathrm{mg} / \mathrm{L}$ (Table 1). Calcium levels in shallow groundwater range from 66 to $381 \mathrm{mg} / \mathrm{L}$ and for deep groundwater, from 2 to $211 \mathrm{mg} / \mathrm{L}$, whereas concentrations of $\mathrm{Mg}^{2+}$ in shallow groundwater samples vary from 29 to $707 \mathrm{mg} / \mathrm{L}$, while deep groundwater has $\mathrm{Mg}^{2+}$ concentrations of $5-260 \mathrm{mg} / \mathrm{L}$. Over $77 \%$ of the shallow groundwater samples exceeded the desirable limits of $\mathrm{Na}^{+}, \mathrm{Mg}^{2+}$ and $\mathrm{Ca}^{2+}$ concentrations for drinking water standards, while most of the groundwater from deep aquifers falls within the permissible drinking water limits; only a few samples were above the prescribed limits for $\mathrm{Na}^{+}$ and $\mathrm{Mg}^{2+}$ (Table 1). Potassium concentrations in shallow groundwater ranged from 26 to $88 \mathrm{mg} / \mathrm{L}$, whereas in deep groundwater, the range was from 1 to $86 \mathrm{mg} / \mathrm{L}$ in the study region. Only 4 deep groundwater samples did not comply with the drinking water limits, and all shallow groundwater samples exceeded the allowable limit as prescribed by [39].

\section{Hydrogeochemical facies and geochemical processes}

To evaluate the hydro-geochemistry of groundwater in the Heuningnes Catchment, the Piper diagram was used [10]. Various studies [16, 18, 29] have applied the concept of hydrogeochemical facies to understand the chemical character of water in aquifer systems. Piper diagrams enable the identification of prominent groundwater types based on the hydrogeochemical process and dominant ions present, which in turn expose the origin of ions and composition of groundwater [42]. In the Piper diagram, the diamond-shaped field displays the composition of water with respect to both cations (left triangle) and anions (right triangle) (Fig. 4). Most of the samples in this study are confined in the field of $\mathrm{Na}^{+}-\mathrm{Cl}^{-}$type, $\mathrm{Na}^{+}-\mathrm{K}$ type and $\mathrm{Cl}^{-}$type because of dominant $\mathrm{Na}^{+}$and $\mathrm{Cl}^{-}$ions in the groundwater (Fig. 4). Water plotting in this field of $\mathrm{Na}^{+}-\mathrm{Cl}^{-}$type is indicative of water derived from marine or deep ancient groundwater [18]. Only three samples (STR1, GYS1 and PZ 19) evolve from $\mathrm{Ca}^{2+-} \mathrm{HCO}_{3}{ }^{-}$type to $\mathrm{Na}^{+}-\mathrm{Cl}^{-}$type, and the same samples also indicate no dominant type and fall in the $\mathrm{HCO}_{3}{ }^{-}$field (Fig. 4).

Evaluation of the water types by means of Piper plot suggests influence of seawater intrusion/saline water within the study region. This is supported by the fact that in the area, the alkali cations $\left(\mathrm{Na}^{+}\right.$and $\left.\mathrm{K}^{+}\right)$overpower the alkaline earth cations $\left(\mathrm{Mg}^{2+}\right.$ and $\left.\mathrm{Ca}^{2+}\right)$ and anions of strong acids $\left(\mathrm{SO}_{4}{ }^{2-}\right.$ and $\left.\mathrm{Cl}^{-}\right)$dominated over weak acids $\left(\mathrm{HCO}_{3}{ }^{-}\right.$and $\left.\mathrm{CO}_{3}{ }^{-}\right)$. The dominance of $\mathrm{Na}^{+}, \mathrm{Cl}^{-}$and $\mathrm{SO}_{4}{ }^{2-}$ ions over other ions causes the increase in the $\mathrm{EC}$ and TDS observed in the area. Therefore, using the Piper diagram alone, one could easily conclude that the groundwater was derived from seawater, yet other processes also need to be evaluated such as evaporation, precipitation or rock-water interaction which have an influence in the quality.

Using the Gibbs plot, conclusions concerning the influence of various dominant geochemical processes such as precipitation, rock-water interaction mechanism and evaporation in controlling the hydrochemistry of groundwater in the aquifer can be deduced [21]. Most samples in the study region were confined in the rock-dominant and evaporation dominant zone (Fig. 5) indicating that the chemical composition of groundwater in the Heuningnes Catchment is a result of chemical weathering of aquifer lithology followed by evaporation and seawater mixing for samples plotted beyond $10,000 \mathrm{mg} / \mathrm{L}$. This is expected in semi-arid regions as stated by [34] where climate conditions tend to increase the rate of evaporation, which in turn increases the TDS, $\mathrm{Na}^{+}$and $\mathrm{Cl}^{-}$concentrations, causing the water to be saline as observed herein. The dominance of rock-water interaction suggests that groundwater in the area had sufficient time to interact with the lithology material and in the course of this interaction, different ions were released into the water. Similar results were obtained in a study done by $[21,26,31]$ using the Gibbs plot to differentiate between mechanisms 


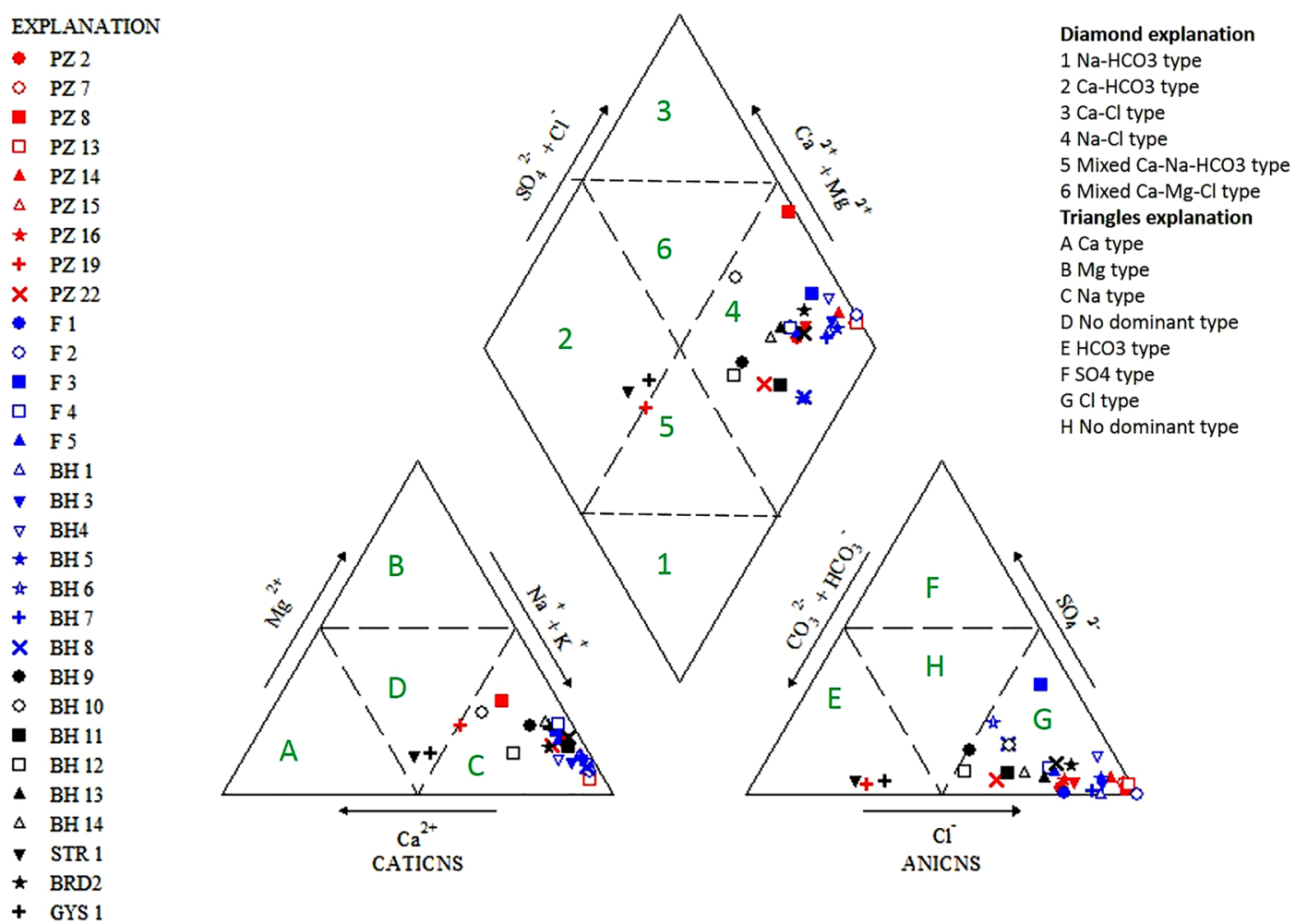

Fig. 4 Piper diagram showing groundwater type in Heuningnes Catchment

Fig. 5 Gibbs diagram of groundwater in the study area

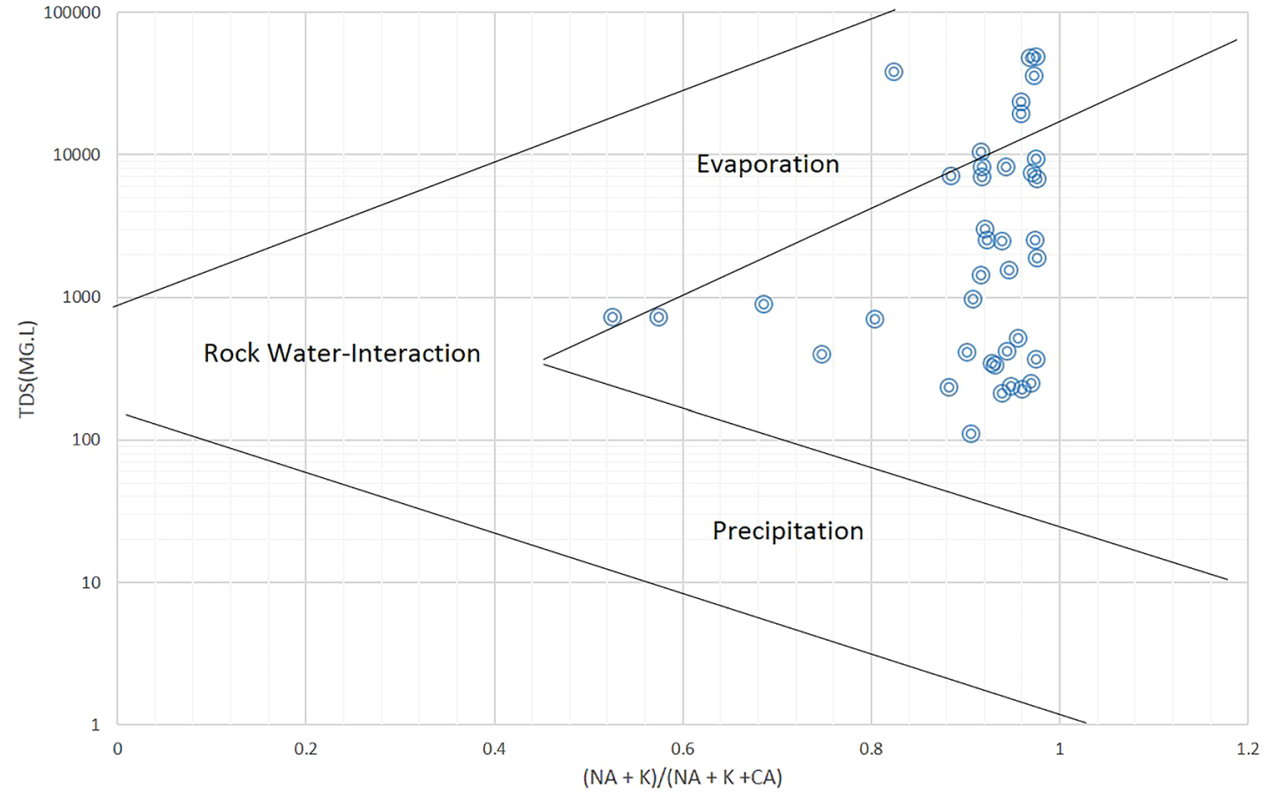

controlling groundwater and surface water chemistry. The majority of samples suggested that the chemical weathering of rock-forming minerals is influencing the groundwater quality.

\section{Assessing quality of groundwater for irrigation uses}

Concentrations of dissolved salts mainly control the quality of irrigation water. High salt content in water 
used for irrigation may upset the soil structure together with the permeability rate and aeration, ultimately disturbing plant growth $[9,15]$. The assessment of groundwater quality for irrigation uses in this study was based on the estimation of various parameters such as salinity hazard (EC), sodium per cent $\left(\mathrm{Na}^{+} \%\right)$, sodium adsorption ratio (SAR), Kelly's ratio (KR), permeability index (PI) and magnesium ratio $(\mathrm{MH})$; the results are tabulated in Table 3. Also, $\mathrm{HCO}_{3}{ }^{-}, \mathrm{Cl}^{-}, \mathrm{SO}_{4}{ }^{2-}$ and TDS were considered.

\subsection{Salinity hazard (EC)}

The total concentration of dissolved salts in irrigation water can be expressed in electrical conductivity (EC) for classification purposes. In this study, we follow the classification by FAO [1] for irrigation use. In their guidelines, $E C$ is grouped into three classes based on the relationship between the EC of water and the EC of saturated soil extracts, to indicate the salinity hazard. There is no problem with salinity if the water has an $\mathrm{EC}<750 \mu \mathrm{S} / \mathrm{cm}$. An EC between 750 and $3000 \mu \mathrm{S} / \mathrm{cm}$ indicates an increasing problem of the salinity, and lastly, when EC $>3000 \mu \mathrm{S} /$ $\mathrm{cm}$, there is a severe problem of salinity. In the study area, the shallow groundwater samples fall within the $3^{\text {rd }}$ class where $E C$ is above $3000 \mu \mathrm{S} / \mathrm{cm}$ suggesting a severe problem of salinity, except for one sample that falls in the second class of increasing problem. This therefore suggests that shallow groundwater in the area is not suitable for irrigation. As for deep groundwater, 11 of the samples fall in the first class indicating no problem of salinity having an $\mathrm{EC}<750 \mu \mathrm{S} / \mathrm{cm}$, whereas 6 samples fall in the second class and only 5 samples are not suitable for irrigation as they fall in the $3 \mathrm{rd}$ class with EC $>3000 \mu \mathrm{S} / \mathrm{cm}$. Overall, $35.4 \%$ of the groundwater (both shallow and deep) in the area is suitable for irrigation in terms of the salinity hazard, whereas $42 \%$ of the groundwater poses high salinity hazard and is not to be used for irrigation purposes (Table 3) except for very salt-tolerant plants whereby exceptional drainage, frequent leaching and intensive management are available.

\subsection{Sodium adsorption ratio (SAR)}

Sodium adsorption ratio (SAR) is the effective parameter used for ascertaining the fitness of groundwater for irrigation purposes because it is a measure of alkali/sodium hazard for plants [2]. High sodium in irrigation water affects the soil condition by reducing its permeability and raising its hardness $[4,17]$. The sodium adsorption ratio (SAR) is an index of the potential of a given irrigation water to induce sodic soil conditions. Sodicity in irrigation water is a consequence of high concentrations of $\mathrm{Na}^{+}$relative to $\mathrm{Ca}^{2+}$ and $\mathrm{Mg}^{2+}$. In South African Water Quality Guidelines (SAWQG), the sodium hazard is divided into four categories (Table 3 ).

The results of calculated SAR from water samples in the study region indicate that $48.4 \%$ have low sodium concentration and are acceptable for irrigation use and pose no risk of exchangeable sodium (Table 3 ). According to
Table 3 Classification of groundwater samples for irrigation suitability

\begin{tabular}{|c|c|c|c|c|}
\hline Parameter & Range & Water class & No. of samples & $(\%)$ \\
\hline \multirow[t]{3}{*}{ SAR (meq/l) } & $<2$ & Excellent & 0 & 0 \\
\hline & $2-8$ & Good & 15 (14DGW, 1SGW) & 48.4 \\
\hline & $8-15$ & Doubtful & 1 (SGW) & 3.2 \\
\hline$P$ & $>15$ & Unsuitable & $15(8 \mathrm{DGW}, 7 \mathrm{SGW})$ & 48.4 \\
\hline \multirow[t]{2}{*}{$\mathrm{KR}(\mathrm{meq} / \mathrm{l})$} & $<1$ & Suitable & 3 (2DGW, 1SGW) & 9.7 \\
\hline & $>1$ & Unsuitable & 28 (20DGW, 8SGW) & 90.3 \\
\hline \multirow{3}{*}{$\begin{array}{c}\text { Salinity hazard } \\
E C(\mu \mathrm{S} / \mathrm{cm})\end{array}$} & $<750$ & No problem of alkalinity & 11 (DGW) & 35.4 \\
\hline & $750-3000$ & Increasing problem of alkalinity & 7 (6DGW, 1SGW) & 22.6 \\
\hline & $>3000$ & Severe problem of alkalinity & 13 (5DGW, 8SGW) & 42 \\
\hline \multirow[t]{5}{*}{$\mathrm{Na} \%$ (meq/l) } & $<20$ & Excellent & 0 & 0 \\
\hline & $20-40$ & Good & 0 & 0 \\
\hline & $40-60$ & Permissible & 5 (3DGW, 2SGW) & 16.1 \\
\hline & $60-80$ & Doubtful & $14(10 \mathrm{DGW}, 4 \mathrm{SGW})$ & 45.2 \\
\hline & $>80$ & Unsuitable & 12 (9DGW, 3SGW) & 38.7 \\
\hline \multirow[t]{2}{*}{$\mathrm{MH}(\mathrm{meq} / \mathrm{l})$} & $<50$ & Suitable & 3 (2DGW, 1SGW) & 9.7 \\
\hline & $>50$ & Unsuitable & 28 (20DGW, 8SGW) & 90.3 \\
\hline \multirow[t]{3}{*}{$\mathrm{PI}(\mathrm{meq} / \mathrm{l})$} & Class I (> 75\%) & Good & 29 (21DGW, 8SGW) & 93.5 \\
\hline & Class II (75-50\%) & Permissible & $2(1 \mathrm{DGW}, 1 \mathrm{SGW})$ & 6.5 \\
\hline & Class III (<25\%) & Unsuitable & 0 & 0 \\
\hline
\end{tabular}

$D G W$ deep groundwater, SGW shallow groundwater 
[37], irrigation water with high SAR introduces problems in the soil and damages the soil structure due to dispersion of clay particles. In this study, $48.4 \%$ indicate high SAR and are not suitable for irrigation, and using this water for irrigation will negatively affect the crop yield and quality as a result of sodium uptake through the roots of sodium sensitive plants [6].

\subsection{Infiltration hazard (SAR and EC)}

Infiltration problems exist when irrigation water is unable to enter the soil fast enough during a normal irrigation cycle and the water remains on the soil surface for some time, thus causing poor supply to the crops. Infiltration is affected by both SAR and EC of irrigation water; therefore, these parameters must be assessed in unison to estimate water infiltration hazard. The findings of this study indicate that $48.3 \%$ of the groundwater samples will not cause any infiltration problems according to the South Africa Water Quality Guideline [6] as well as the FAO (1976), whereas $42 \%$ of the samples are likely to cause moderate infiltration problems (Table 4). Only $9.7 \%$ will cause severe problems. All of the shallow groundwater samples indicated no problem of infiltration, and this is because increased salt concentration (higher EC) in water helps maintain soil structure; however, it should be noted that higher EC increases salt hazard. As indicated in Table 3, shallow groundwater in this area is not suitable for irrigation because of high salinity hazard.

\subsection{Percentage sodium ( $\mathrm{Na} \%)$}

Sodium is a good indicator of irrigation water quality because in irrigation water with a high concentration of $\mathrm{Na}^{+}$, the sodium ions are inclined to attach themselves to the clay particles. Consequently, the $\mathrm{Ca}^{2+}$ and $\mathrm{Mg}^{2+}$ ions are replaced by the $\mathrm{Na}^{+}$. During the exchange process in the soil of $\mathrm{Ca}^{2+}$ and $\mathrm{Mg}^{2+}$ for $\mathrm{Na}^{+}$from the water, this leads to aggregates of some soils to disperse, causing sealing

Table 4 Evaluating the risk of sodium in irrigation water causing a water infiltration problem in soil. Modified after DWAF [6]

\begin{tabular}{|c|c|c|c|}
\hline \multicolumn{4}{|c|}{ Risk of water infiltration problem } \\
\hline \multirow[b]{2}{*}{ SAR (meq/l) } & No problem & Moderate & Severe \\
\hline & \multicolumn{3}{|c|}{ EC of water $(\mu \mathrm{S} / \mathrm{cm})$} \\
\hline$<3$ & $>900$ & $200-900$ & $<200$ \\
\hline $3-6$ & $>1300$ & $250-1300$ & $<250$ \\
\hline $6-12$ & $>2000$ & $350-2000$ & $<350$ \\
\hline $12-20$ & $>3100$ & $900-3100$ & $<900$ \\
\hline$>20$ & $>5600$ & $1800-5600$ & $<1800$ \\
\hline \# of samples & 15 (48.3\%) & $13(42 \%)$ & $3(9.7 \%)$ \\
\hline
\end{tabular}

of soil pores and a reduction in permeability to water flow [15]. Then, the soil becomes hard and compact when dry and restricts water penetration. Using irrigation water with $\mathrm{Na} \%$ beyond 60 is not recommended as it could influence accumulation of sodium which absolutely causes destruction in the soil structure and minimises both aeration and infiltration competences thereby impeding plant growth. Bhat et al. [4] state that dissolution of minerals from lithologies, introduction of chemical fertilizers with irrigation waters and extended residence time are the causes of higher $\mathrm{Na}^{+}$in the groundwater. The results of $\mathrm{Na} \%$ for the study are tabulated in Table 3, and the calculated $\mathrm{Na} \%$ values can be found in Online Resource 6-7. Most of the samples in the area are confined in the last two classes, which are the doubtful and unsuitable categories, about $45.2 \%$ and $38.7 \%$, respectively. Only $16.1 \%$ of the water samples meet the $\mathrm{Na} \%$ standards for irrigation use. Of all the samples, $38.7 \%$ had concentrations of sodium over $80 \%$ and are therefore not fit for irrigation. Using this water for irrigation in the study region most probably will have a toxic influence on crops, eventually causing the soil to be resistant to water penetration because of the dispersed soil colloidal particles [15].

\subsection{Kelly's ratio (KR) and magnesium hazard (MH)}

Irrigation water with Kelly's ratio $<1$ is accepted for irrigation; anything above this value indicates an excess level of sodium in the water and should not be used for irrigation purposes. Using both $\mathrm{KR}$ and $\mathrm{MH}$, similar results were found where the calculated results indicate that only 9.7\% (3 samples) of the groundwater samples from both shallow and deep boreholes are fit for irrigation and the remaining $90.3 \%$ (28 samples) are not appropriate for irrigation (Table 3 ). The samples with $\mathrm{MH}>50$ pose high risk of alkaline soil and are consequently not recommended for irrigation. This indicates that the water in the study region is not of permissible quality for irrigation purposes. Using KR to assess water quality for irrigation, [4] found that $50 \%$ of their samples were suitable for irrigation and $50 \%$ were not. This demonstrates that using both $\mathrm{KR}$ and $\mathrm{MH}$ yields a more accurate result.

\subsection{Permeability Index (PI)}

The permeability index is defined in three classes, according to [3]: irrigation water with high permeability index (>75\%) is classified as Class I; Class II has permeability index between 75 and 50\%; these two classes are considered excellent for irrigation use, while a third category (Class III) has a permeability index $<25 \%$ and is not suitable for irrigation purposes. In the present study, PI values vary from 60.2 to $98.2 \%$ (Table 3 ). Considering the PI

SN Applied Sciences 
classification, almost $93.5 \%$ of the tested samples are Class I, while $6.5 \%$ of the samples belong to Class II. This means that the quality of water in the sampled area is suitable for irrigation use.

\section{Conclusions}

The overall groundwater quality in the study area is fresh to brackish and mostly acidic to alkaline in nature. Analysis of the hydrochemical data indicates that the groundwater in the study area is highly impacted by salinity and based on the Piper diagram, it is of $\mathrm{Na}^{+}-\mathrm{Cl}^{-}$water type. The abundance of total cations decreases in the order of $\mathrm{Na}^{+}>\mathrm{Mg}^{2+}>\mathrm{Ca}^{2+}>\mathrm{K}^{+}$and of anions in the order $\mathrm{Cl}^{-}>\mathrm{HCO}^{3-}>\mathrm{SO}_{4}{ }^{2+}$. The quality of groundwater in the area is mostly influenced by chemical weathering of rockforming minerals, and evaporation has a minor influence based on Gibbs' diagram. Shallow groundwater in the study area is highly contaminated by salinisation and thus not suitable for drinking purposes, but in this regard, deep groundwater is safe for drinking purposes. The high concentrations of $\mathrm{Cl}^{-}, \mathrm{Na}^{+}$, TDS and EC indicate that groundwater in the study area is significantly degraded in water quality and suffers from extensive salinisation due to seawater mixing and the influence of the geological setting. However, some samples from the deep aquifer showed that the water quality was reasonable and would require treatment prior use. Assessing suitability of water for irrigation use suggests that sulphate is not a concern in the area; however, the rest of the parameters indicate that the majority of shallow groundwater in the area is not suitable for irrigation purposes based on SAR, Na\%, EC, $\mathrm{KR}, \mathrm{MH}$ and $\mathrm{PI}$. Considering all the parameters combined, it appears that groundwater from deep aquifer is better suitable for irrigation compared to shallow groundwater (Online Source 4-5).

These conclusions signal a problem for this area, since crop farming for commercial use is widely practiced in the area; therefore, to gain profit out of farming, it is important that the texture of the soil is coarse-grained or organic, with high permeability. As this study has shown that almost all groundwater has high salinity, it is recommended to plant crop varieties that are highly salinity tolerant, as treating the water prior to irrigation would not be economically viable. This study also recommends that a monitoring programme should be implemented to evaluate spatial and temporal variations in chemical composition of groundwater in the area covering different seasons.

Acknowledgments This paper is a part of the PhD project of the corresponding author. The study also forms part of a Water Research
Commission funded project. The authors gratefully acknowledge the National Research Foundation for their financial assistance.

Author's Contribution PM was responsible for drafting of the article, conception and design, acquisition, analysis and interpretation of data, and JVBD and TK were responsible for reviewing, revising and for the final approval of the article.

Funding This research was funded by National Research Foundation (NRF) and the Water Research Commission (WRC).

Data availability (Data transparency): The data used to support the outcomes of this study have been included within the supplementary material.

\section{Compliance with ethical standards}

Conflict of interest The authors declare that they have no conflict of interest.

\section{References}

1. Ayeres R.S (1976) Water quality for agriculture. Food and Agricultural Organization of the United Nations, Rome. Irrigation and drainage paper, no. 29

2. Badana N, Vetrimurugan E, Natarajan R (2018) Coastal aquifer contamination and geochemical processes evaluation in Tugela catchment, South Africa-geochemical and statistical approaches. Water 10(6):687. https://doi.org/10.3390/w1006 0687

3. Bashir E, Naseem S, Pirzada T (2013) Geochemical study of groundwater of Uthal and Bela areas, Balochistan and its appraisal for drinking and irrigation water quality. Int J Agric Environ 2:1-13

4. Bhat MA, Wani AS, Vijay K, Jyotirmaya S, Dinesh T (2018) An overview of the assessment of groundwater quality for irrigation. $J$ Agric Sci Food Res 9:209

5. Deshpande SM, Aher KR (2012) Evaluation of groundwater quality and its suitability for drinking and agriculture use in parts of Vaijapur, District Aurangabad, MS, India. Res J Chem Sci 2(1):25-31

6. DWAF (Department of Water Affairs and Forestry) (1996) South African water quality guidelines, 2 nd edn, vol 4. Agricultural use: irrigation

7. Eyinla D, Oladunjoye MA (2014) Improving quality agricultural practices in tropical environments through integrated geophysical methods. IOSR J Appl Geol Geophys (IOSR-JAGG) 2(5):128-139

8. Freeze RA, Cherry JA (1979) Groundwater. Prentice-Hall Inc, Englewood Cliffs, p 604

9. Gorthi KV, Mohan Babu M (2015) Groundwater studies with special emphasis on seasonal variation of groundwater quality in a coastal aquifer. J Geol Geophys 4:210. https://doi. org/10.4172/2381-8719.1000210

10. He S, Li P (2019) A MATLAB based graphical user interface (GUI) for quickly producing widely used hydrogeochemical diagrams. Geochemistry. https://doi.org/10.1016/j.chemer.2019.125550

11. He X, Li P, Ji Y, Wang Y, Su Z, Elumalai V (2020) Groundwater arsenic and fluoride and associated arsenicosis and fluorosis in China: occurrence, distribution and management. Expo Health. https://doi.org/10.1007/s12403-020-00347-8 
12. He X, Li P, Wu J, Wei M, Ren X, Wang D (2020) Poor groundwater quality and high potential health risks in the Datong Basin, northern China: research from published data. Geochem Health, Environ. https://doi.org/10.1007/s10653-020-00520-7

13. Herdien EL, Petersen C, Reed C, Impson D, Belcher A, Ndiitwani T, Buthelezi S, Matoti A (2005) Technical Report: Ecological status for rivers of the Overberg region 2004/2005

14. Hosseinifard SJ, Aminiyan MM (2015) Hydrochemical characterization of groundwater quality for drinking and agricultural purposes: a case study in Rafsanjan Plain, Iran. Water Qual Expo Health 7:531-544. https://doi.org/10.1007/s12403-015-0169-3

15. Hussain M, Rao DP (2013) Assessment of the ground water quality and its suitability for drinking and irrigation purposes: a case study of Patancheru, Andhra Pradesh, India. Arch Appl Sci Res 5(6):232-238

16. Hwang JY, Park S, Kim HK, Kim MS, Jo HJ, Kim Jl, Lee GM, Shin IK, Kim TS (2017) Hydrochemistry for the assessment of groundwater quality in Korea. J Agric Chem Environ 6:1-29. https://doi. org/10.4236/jacen.2017.61001

17. Islam SMD, Bhuiyan MAH, Rume T, Azam G (2017) Hydrogeochemical investigation of groundwater in shallow coastal aquifer of Khulna District, Bangladesh. Appl Water Sci 7:4219-4236. https://doi.org/10.1007/s13201-017-0533-5

18. Khan A, EghbalBakhtiari A (2017) Groundwater assessment of coastal aquifers in Karachi: impact of seawater intrusion. Int J Ground Sediment Water 6:248

19. Kitoni I (2018) Integrated hydrological modeling of surface and groundwater interactions in Heuningnes catchment (South Africa). Dissertation, University of Twente

20. Kokkat A, Jegathambal P, James EJ (2016) Spatial and temporal variation in groundwater quality and impact of sea water in the Cauvery delta, South India. Int J Earth Sci 9(3):383-392

21. Kumar PJS (2016) Deciphering the groundwater-saline water interaction in a complex coastal aquifer in South India using statistical and hydrochemical mixing models. Model Earth Syst Environ 2:194. https://doi.org/10.1007/s40808-016-0251-2

22. Li P, He S, Yang N, Xiang G (2018) Groundwater quality assessment for domestic and agricultural purposes in Yan'an City, northwest China: implications to sustainable groundwater quality management on the Loess Plateau. Environ Earth Sci 77(23):775. https://doi.org/10.1007/s12665-018-7968-3

23. Li P, Wu J, Qian H (2016) Hydrochemical appraisal of groundwater quality for drinking and irrigation purposes and the major influencing factors: a case study in and around Hua County, China. Arab J Geosci 9(1):15. https://doi.org/10.1007/s1251 7-015-2059-1

24. Li P, Wu J, Qian H, Zhang Y, Yang N, Jing L, Yu P (2016) Hydrogeochemical characterization of groundwater in and around a wastewater irrigated forest in the south-eastern edge of the Tengger Desert, Northwest China. Expo Health 8(3):331-348. https://doi.org/10.1007/s12403-016-0193-y

25. Li P, Wu J, Tian R, He S, He X, Xue C, Zhang K (2018) Geochemistry, hydraulic connectivity and quality appraisal of multilayered groundwater in the Hongdunzi coal mine, northwest China. Mine Water Environ 37(2):222-237. https://doi.org/10.1007/ s10230-017-0507-8

26. Madhav S, Ahamad A, Kumar A, Kushawaha J, Singh P, Mishra PK (2018) Geochemical assessment of groundwater quality for its suitability for drinking and irrigation purpose in rural areas of Sant Ravidas Nagar (Bhadohi), Uttar Pradesh. Geol Ecol Landsc 2(2):127-136. https://doi.org/10.1080/24749508.2018.1452485
27. Manyama KM (2017) Hydrogeophysical characterisation of shallow coastal aquifers in the Western Cape, South Africa. M.Sc. Dissertation, University of the Western Cape

28. Mazvimavi D (2018) Finding "new" water to address conflicting and competing water demands in the Nuwejaars Catchment, Cape Agulhas. WRC Report No 2324/1/18

29. Nwankwoala HO, Udom GJ (2011) Hydrogeochemical evaluation of groundwater in parts of Eastern Niger Delta, Nigeria. J Acad Appl Stud 1(2):33-58

30. Pauw T (2012) Assessment of spot 5 and ers-2 Obia for mapping wetlands. Dissertation, University of Stellenbosch

31. Prasanna MV, Chidambaram S, Gireesh TV, Jabir Ali TV (2010) A study on Hydrochemical characteristics of surface and subsurface water in and around Perumal Lake, Cuddalore District, Tamilnadu, South India. Environ Earth Sci. https://doi. org/10.1007/s12665-010-0664-6

32. Prusty P, Farooq SH, Zimik HV, Barik SS (2018) Assessment of the factors controlling groundwater quality in a coastal aquifer adjacent to the Bay of Bengal, India. Environ Earth Sci 77:762. https://doi.org/10.1007/s12665-018-7943-z

33. Raheli-Namin S, Mortazavi M, Mobinifar MA (2016) Groundwater-quality probability mapping and assessment for domestic and irrigation purposes in Ghara-su Basin of Golestan Province, Iran. J Mater Environ Sci 7(1):259-271

34. Rivera-Hernández JR, Green-Ruiz C, Pelling-Salazar L, TrejoAlduenda A (2017) Hydrochemistry of the Mocorito river coastal aquifer, Sinaloa, Mexico: water quality assessment for human consumption and agriculture suitability. Hidrobiológica 27(1):103-113

35. Russel IA, Impson ND (2006) Aquatic systems in and adjacent to Agulhas National Park with particular reference to the fish fauna. Koedoe 49(2):45-57

36. SANS (2011) South African National Standards (SANS 241). Drinking water: quality requirements

37. Shah SM, Mistry NJ (2013) Groundwater quality assessment for irrigation use in Vadodara District, Gujarat, India. Int J Biol Biomol Agric Food Biotechnol Eng 7(7):719-724. https://doi. org/10.5281/zenodo.1087474

38. Weight WD (2008) Hydrogeology field manual, 2nd edn. McGraw-Hill Companies Inc., New York

39. WHO (2011) Hardness in drinking-water: background document for development of WHO guidelines for drinking-water quality

40. Wu J, Wang L, Wang S, Tian R, Xue C, Feng W, Li Y (2017) Spatiotemporal variation of groundwater quality in an arid area experiencing long-term paper wastewater irrigation, northwest China. Environ Earth Sci 76(13):460. https://doi.org/10.1007/ s12665-017-6787-2

41. Wu J, Zhou H, He S, Zhang Y (2019) Comprehensive understanding of groundwater quality for domestic and agricultural purposes in terms of health risks in a coal mine area of the Ordos basin, north of the Chinese Loess Plateau. Environ Earth Sci 78(15):446. https://doi.org/10.1007/s12665-019-8471-1

42. Zakaria N, Akiti TT, Osae S, Adomako D, Ganyaglo Samuel Y, Hanson KEK, Ayanu G (2012) Hydrogeochemistry of groundwater in parts of the Ayensu Basin of Ghana. Proc Int Acad Ecol Environ Sci 2(2):128-135

Publisher's Note Springer Nature remains neutral with regard to jurisdictional claims in published maps and institutional affiliations. 